\title{
The Scientific Network of Surfactants: Structural Analysis
}

\author{
Rafael Bailón-Moreno and Encarnación Jurado-Alameda \\ Departamento de Ingeniería Química, Facultad de Ciencias, Universidad de Granada, Campus de \\ Fuentenueva, 18701, Granada, Spain. E-mail: \{bailonm, ejurado\}@ugr.es \\ Rosario Ruiz-Baños \\ Departamento de Biblioteconomía y Documentación, Facultad de Biblioteconomía y Documentación, \\ Universidad de Granada, Campus de Cartuja, 18701, Granada, Spain. E-mail: rruizb@ugr.es
}

\begin{abstract}
The scientific network of the surfactants and related subjects has been analyzed with the CoPalRed ${ }^{\odot}$ knowl- $^{\circ}$ edge system. The actors studied have been countries, research centers and laboratories, researchers, and journals. The thematic map of the major research areas has been established. Most of the research areas, and those that have the greatest representation in terms of number of documents, are related to physics and chemistry. However, biochemistry and cell biology, medicine (pediatrics and pulmonary physiology), and, to a lesser extent, veterinary medicine and food science and technology are also noteworthy in the field of surfactants, which presents a markedly multidisciplinary profile.
\end{abstract}

\section{Introduction}

Scientific and technological activity is manifested through scientific and technical documents. Notable among these are journal articles and invention patents, the former mainly in the sphere of science and the latter in technology. All documents are subject to rigorous review by specialists in the subject, which implies that the content has great informative power (Callon, Courtial, \& Penan, 1995).

In addition, scientific activity is growing at a dizzying pace. The pioneering studies of Price are well known. They establish the laws of the growth of science-exponential and logistical - that apply myriad variables related to the size of the field: number of researchers, universities founded, specialized journals, chemical elements discovered, increase in bibliographic databases such as Chemical Abstracts, etc. (Price, 1963). Clearly, humans are limited in their capacity to read and assimilate scientific documents. That capacity is approximately constant, but in many cases the number of documents is growing exponentially. All these characteristics cause the scientist gradually to lose a general view of his or

Received December 6, 2004; revised February 1, 2005; accepted May 13, 2005

(C) 2006 Wiley Periodicals, Inc. • Published online 17 March 2006 in Wiley InterScience (www.interscience.wiley.com). DOI: 10.1002/asi.20362 her scientific field. The condition of having more and more information, journals, documents, but at the same time being more and more isolated, lost, and with the private sensation that there is an endless mass of information that should be acquired but cannot be embraced because of the impossibility of reading it all is the result (Callon et al., 1995).

Recently, the so-called knowledge engineering method has emerged as an aid to the researcher. It consists of a set of techniques, methods, and even computer tools that enable the user to read automatically thousands of scientific documents, analyze them, relate them to each other, synthesize them, and draw conclusions or positive knowledge-that is, knowledge that allows researchers to make decisions that are justified by accurate information. In short, knowledge engineering seeks to imitate the behavior of a scientist, but instead of handling a few dozen or hundreds of documents, it manages thousands and even hundreds of thousands of documents simultaneously (Polanco, 1997). An example of knowledge engineering is the $\mathrm{CoPalRed}^{\circledR}$ System, used in the present work (Bailón-Moreno, 2003). A beta version has been used, but in the future a commercial version in http:// ec3.ugr.es/copalred will be available.

\section{Objectives}

Surfactants and related materials constitute one of the most vigorous fields in chemistry, so much so that it is not restricted to the purely physicochemical field, but also overlaps a multitude of other scientific areas. In addition, it makes use of numerous actors (research centers, researchers, resources, etc.), an indication of its enormous size. Although we call it a subarea, its dimensions cause researchers to know more or less only their own small scientific corner and have a vague idea of the rest.

The present work tries to provide a panorama of the scientific field of surfactants and related subjects, sufficiently general to cover it all but detailed enough to allow the image to be as sharp as possible. To do so, it is necessary to make a 
structural analysis of the scientific network of the surfactants by means of the engineering of the knowledge, with the goal of gaining greater knowledge on this scientific area.

\section{Materials and Methods}

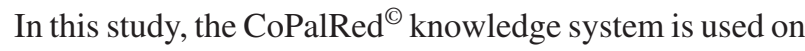
a set of 63,543 bibliographic references of scientific articles within the period 1993-2002. These references have been downloaded via the Internet from the Science Citation Index $(S C I)$, expanded version, of the Institute for Scientific Information (ISI). The query for the search was the following:

\section{SURFACTANT* OR DETERGENT* OR TENSIDE* OR CLEANER* OR LAUNDRY* OR FRAGRANCE* OR PERFUME* OR FLAVOR* OR ODOR* OR (ESSENTIAL SAME OIL*) OR COSMETIC* OR TOILETRY* OR SOAP*}

As a first step, the productivity values were found, expressed as published articles, by countries, by research centers, by authors, and by journals. Productivity values provide a univariate representation of scientific activity of the area. A more thorough relational analysis can be made by drawing a map of the thematic network. The tool used, CoPalRed ${ }^{\odot}$, is based on co-word analysis, a scientometric tool of proven qualities.

In broad terms, co-word analysis consists of constructing a matrix of adjacency for the cooccurrence of words in scientific texts. When two terms frequently occur together, they are said to be linked, and the intensity of the link is indicated by the equivalency index, $e_{i j}$ :

$$
e_{i j}=\frac{c_{i j}^{2}}{c_{i} c_{j}}
$$

where $c_{i j}$ is the number of documents in which the terms cooccur and $c_{i}$ and $c_{j}$ represent the number of documents in which each appears. When the words appear together, the equivalency index equals unity; when they are never associated, it equals 0 .

Once the links are quantified, by an algorithm called simple centers, groupings or themes, consisting of more strongly linked networks that represent the centers of interest of the researcher, are produced. The formulation of these science networks or maps demands numerous calculations requiring powerful computers in addition to the appropriate software, such as CoPalRed ${ }^{\odot}$. A special characteristic of this knowledge system is the high speed of analysis of the data, even for great amounts of documents. The limit depends on the memory available. It is possible to process up to 100,000 documents with a personal computer. Polysemy, synonymy, and so on, of the key words, the authors's names, and the research centers is controlled easily with CoPalRed ${ }^{\odot}$ (Universidad de Granada, 2005).

Abundant literature is available on this methodology (Callon, Courtial, \& Laville, 1991; Cahlik, 2000; Courtial, 1989, 1990, 1997; Courtial \& Callon, 1991; Courtial,
Callon, \& Sigogneau, 1993; Courtial \& Michelet, 1990; Jurado-Alameda, Bailón-Moreno, \& Ruiz-Baños, 2001, 2002a, 2002b; Law \& Whittaker, 1992; Noyons, 2001; Rip \& Courtial, 1984; Rostaing, 1996; Ruiz-Baños, 1997; Ruiz-Baños \& Bailón-Moreno, 1998, 1999; Stegmann \& Grohmann, 2003).

\section{Countries Producing Articles}

\section{Absolute Production}

Figure 1 lists the production values of articles on surfactants (according to the data of the $S C I$ ) of the 20 countries with the greatest production in the world. The first positions are occupied by developed countries such as the United States of America, Japan, Germany, the United Kingdom, France, Canada, Spain, and Italy. These coincide, especially in the United States, with a relatively high population together with a high gross national product, implying a strong human as well as economic potential.

In this ranking, less developed countries that have a very strong human potential are included: the People's Republic of China, with more than 1.2 billion inhabitants; India, with roughly 1 billion; Brazil, with the more modest population of more than 170 million; and Russia, with some 150 million.

Another group are countries in which economic potential and general development appear greater than their human potential in absolute terms (not in relative terms), and therefore they are situated in good positions: Sweden, Holland, Australia, Switzerland, Taiwan, South Korea, Israel, and Belgium.

In any case, this foremost group of countries produce $85 \%$ of the articles on surfactants, particularly the United States, with $29.5 \%$ of world production.

\section{Production by Human Resources}

If we now consider the countries according to their production per million of inhabitants, performance is expressed independently of country size. In this case, the first positions are held by small countries with populations of 15 million, 10 million, or fewer than 10 million inhabitants: Sweden,

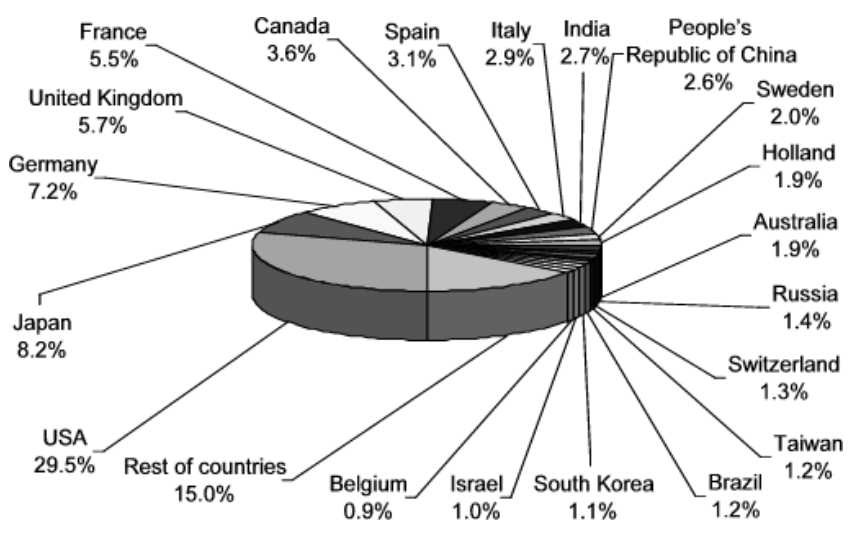

FIG. 1. Relative production of articles on surfactants, by country. 
Switzerland, Israel, Denmark, Finland, Holland, New Zealand, Norway, Belgium, Singapore, Austria, and Ireland. Most are Central or Northern European countries. Among these, from the eighth position on, appear countries with large populations in absolute terms. Thus, for example, the giant United States occupies the eighth place with relative productivity of half that of Sweden. Spain occupies the 17th position, with a productivity of 50 articles per million inhabitants (a third of Sweden). Italy has even lower productivity, in 24th place.

Figure 2 graphically depicts the productivity by human resources of the foremost 10 countries, in which there are only two of great size (Canada and the United States).

\section{Production by Economic Potential}

Another element that should be taken into account is productivity in relation to economic potential. Figure 3 presents a graph of the first 10 countries, where Australia and Bulgaria are notable for having 19.3 and 15.8 articles per $\$ 1,000,000,000$ gross rational product. In this list, the primary positions of the great absolute producers disappear: the United States (49th position!) Japan (69th, the worst), Germany (42nd), United Kingdom (38th), France (36th), and Spain (21st, the best of the prosperous countries).

In general, we find in first position the countries of the so-called Eastern Europe bloc (Bulgaria, Slovakia, Croatia, Hungary, Georgia, Moldavia, Byelorussia, Russia, Ukraine),

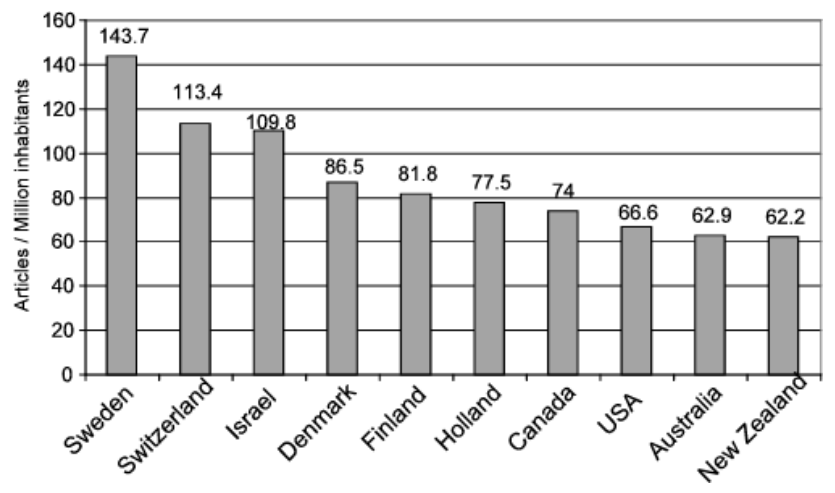

FIG. 2. Productivity of articles per million of inhabitants (top 10 countries).

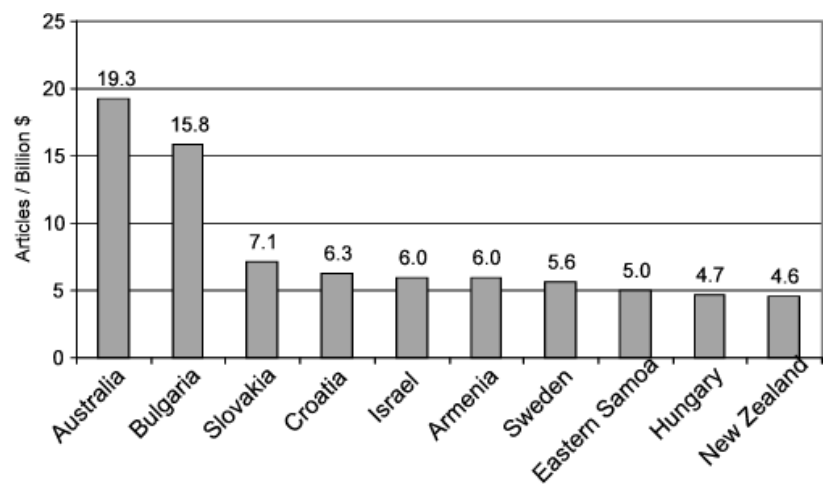

FIG. 3. Production of articles by economic resources (top 10 countries). which demonstrate good use of resources, together with some African countries, accustomed to produce, although little, with extremely limited resources (Zimbabwe, Kenya, Ethiopia).

It becomes evident that the most developed countries, accustomed to having large resources, generate equal quantities of articles, at a habitually high cost. We should ask a Japanese researcher about surfactants and how much that researcher would be able to accomplish if transferred suddenly to Ethiopia.

\section{Research Centers and Laboratories}

A total of 11,229 references to research centers and laboratories were found. This very high number hampers a detailed study of each of these centers. Nevertheless, it is possible to gain an idea of the profile of the most productive centers. A quick analysis indicates that there are fundamentally three types of research centers that work on surfactants:

1. State-owned nonuniversity research centers

2. Universities

3. Companies

This division follows the triple-helix model of scientific and technical innovation (Leydesdorff, 2003).

\section{State-Owned Nonuniversity Research Centers}

Figure 4 shows a bar graph of the differences in productivity of the most notable centers, ranking 1, 2, 3, 5, 6, and 12 in the list of 11,229 centers, with production from 296 to 896 articles. The center with the most articles published is the Consejo Superior de Investigaciones Científicas (CSIC; Council of Higher Scientific Research) of Spain. Next are two centers in the United States of America: the Center for Naval Analyses (Ctr. Naval Anal.) and the U.S. Department of Agriculture Agricultural Research Service (USDA ARS); a center in China: the Chinese Academy of Sciences; two centers in France: Institute National de la Recherche Agronomique (INRA) and Centre National de la Recherche Scientifique (CNRS); and the Russian Academy of Sciences (RAS).

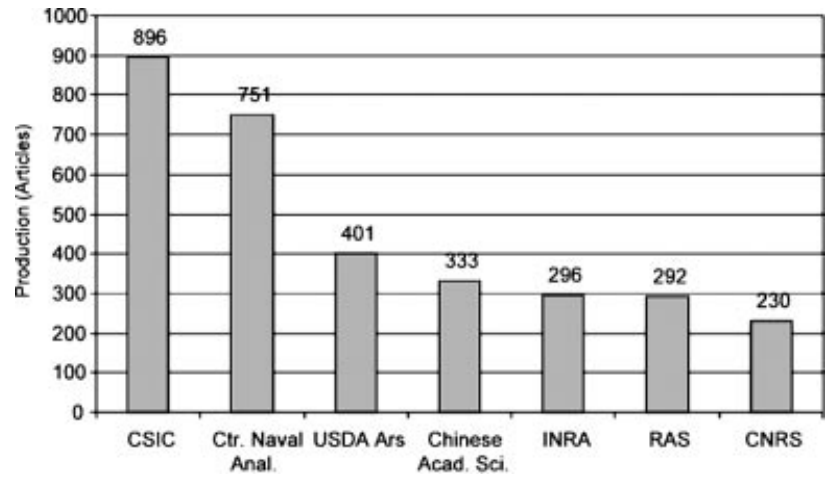

FIG. 4. Main state-owned nonuniversity research centers. 
In more distant positions (157th and 191th, respectively) are two important American organizations: the Food and Drug Administration and the Environmental Protection Agency.

As can be appreciated from a small investigation into the nature of the main state-owned research centers that work on surfactants, they have certain common characteristics: all are multidisciplinary and large, with very high budgets and technical means, and a great quantity of research personnel. Research on surfactants is only a part of their total potential, which covers several scientific fields.

The case of the United States Center for Naval Analyses (CNA) is special because the aim is not scientific or technical research in itself, but rather a support system for the armed forces. Here the binomial research-military relationship is clear.

Another special case is the CSIC of Spain, which is the only one to have a center exclusively dedicated to research on surfactants: El Departamento de Tecnología de los Tensioactivos del CID (Department of Surfactant Technology; Barcelona). This case appears to indicate strong support by the Spanish government of this type of research, with the result of situating the CSIC in the top position of world ranking.

\section{Universities}

Universities are situated slightly below the world ranking of state-owned centers. The most productive is the University of Texas, with a rank of 4 on the general list, with 388 articles, followed by other American universities: University of Wisconsin (258 articles), Cornell University (253), University of Florida (252), and University of CaliforniaBerkeley (222). Although the foremost positions are occupied by state-owned centers, the number of universities is so large that, as a whole, they constitute the most productive group in terms of articles on surfactants. The following are some cases in point.

The leading Japanese university is Kyoto University (221 articles) followed by Tokyo University (216) and at some distance Yokohama University (79). In addition, universities appear from very diverse countries: Hebrew University of Jerusalem (153), University of Sao Paulo (148), and Berlin (104), Munich (103), Cologne (66), and Melbourne (78) Universities. In intermediate positions, there are also American universities, such as University of California-Davis (215), Harvard University (195), and Massachusetts Institute of Technology (MIT) with 189 articles. Spanish universities include Complutense of Madrid, leading with 115 documents, followed by Valencia, Granada, and Barcelona Universities, with 105, 77, and 75 articles, respectively.

It is not necessary to labor the differences of universities from other state-owned research centers-the university professor must devote time both to research and to teaching. For this reason, universities, though very productive, could not be expected to reach the same heights as institutions dedicated exclusively to research.

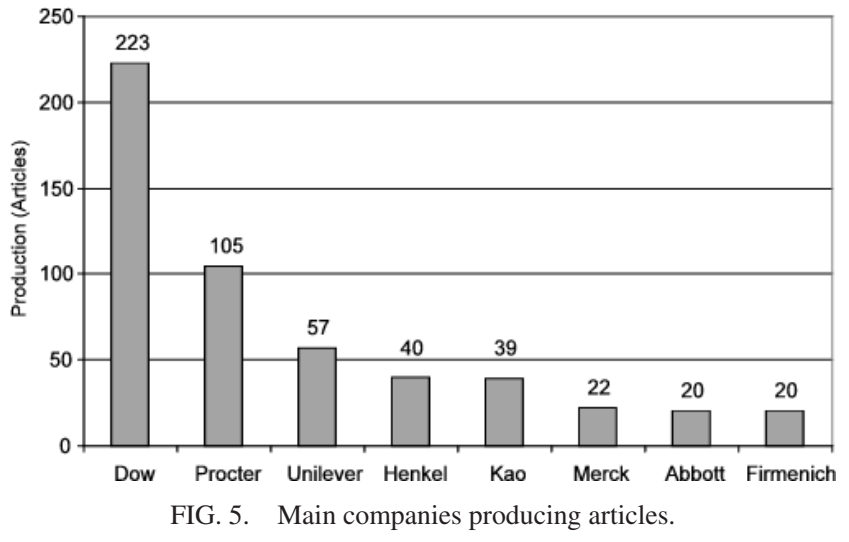

\section{Companies}

The third group of research centers comprises company laboratories. Figure 5 lists the main companies that publish articles. Three basic types are discernible: surfactant producers, consumers of surfactants, and manufacturers of products related to surfactants (e.g., perfumes).

The most important by far is Dow Chemical Co., USA, dedicated to manufacturing and consuming, among many other products, surfactants. Its sales reach $\$ 28$ billion in 170 countries, and it has 50,000 employees. Commercial brands of surfactants owned by Dow are Triton ${ }^{\circledR}$, Dowfax ${ }^{\circledR}$, Tergitol ${ }^{\circledR}$, Hamposyl ${ }^{\circledR}$, and Hampshire ${ }^{\circledR}$. This company also manufactures products used in detergent formulas, such as glycols, polyglycols, ion sequesterers, and alkalis. Triton ${ }^{\circledR}$ surfactants (e.g., Triton 100) are the most widely used in research (The Dow Chemical Company, 2003).

Procter \& Gamble Company is the commercial consumer of surfactants with the most articles published (105). It sells detergents for house cleaning and personal hygiene, cosmetics, and other products. Commercial brands include Ariel, Fairy, Tide, Febreze, Bold, Lenor, Ace, Dash, and Tampax. Established in Cincinnati in 1837 as a family business to manufacture soap and candles, it currently sells 250 products on the market, with some 5 billion consumers (almost $80 \%$ of the world population) in 130 countries (Procter \& Gamble, 2003).

Unilever is one of the strongest competitors of Procter \& Gamble. It sells powder detergents, shampoo, toothpaste, tea, ice cream, oils, and butters for consumers worldwide. Commercial brands include Omo, Ala, Mimosín, Comfort, Domestos, Cif, Axe, Rexona, Sunsilk, Dove, Lux, Pond's, Signal, Close-Up, Calvin Klein, Lipton, Mágnum, Findus, Knorr, and Hellmann's. In 2001, it invested 1,178,000,000€ in research and development ( $2.4 \%$ of the gross worth of the company; Unilever, 2003).

Henkel KgaA, a family company founded in 1876, produces raw materials and finished products. The part of the company specializing in raw materials was recently named Cognis, reserving the name Henkel for finished products. Consumer products are provided by the following divisions:

1. Textile detergents and house cleaners (Mistol, Neutrex, Tenn, Wipp, Dixan, Estrella, Conejo, Bref, Vernel, etc.) 
2. Cosmetics and bath products (Schwarzkopf, Poly Swing, Poly Kur, Fa, La Toja, Neutromed, Diadermine, Denivit, Licor del Polo, Vademécum, etc.)zzz

3. Adhesives (Pret, Tangit, Craftsmen, Duck, Loctite, Pattex, Nural)

With these divisions, sales in 2002 were some 9,656,000,000€, throughout the world (Henkel KGaA, 2003).

Under the name Cognis, its activity is divided into oleochemicals; raw materials for cosmetics, nutrition, and pharmaceutical products; functional products; and chemical products. Some brands are very well known: Cutina, Emulgade, Lanette, Cetiol, Eumulgin, Novata, Texapon, Glucopon. Sales in 2002 reached 3,126,000,000€, with 8,895 employees (Cognis, 2003).

Kao Corporation is a Japanese firm founded in 1887 dedicated to the manufacture and sales of consumer products such as soaps, detergents, shampoos, and cosmetics, as well as producing chemical products for industrial use and providing services related to these products. Sales in 2001 reached $\$ 6,296,600,000$, with 19,923 employees. The products for consumers are usually sold in association with regional companies that form part of the Kao Group; some of its brands are Jul, Gold Well, KMS, Bioré, Curel, White, Magiclean, and Laurier. In Spain, none of these products are sold. On the other hand, it is strong in the sector of raw materials for industry. It manufactures fatty alcohols, surfactants, functional polymers, and raw materials for perfumeries (Kao Corporation, 2002).

The company Merck (Germany) specializes in the pharmaceutical field, manufacturing medicines and vaccines. It also produces chemical and special products for laboratories and cosmetics. In the study period, this company published 22 articles in journals covered by the $S C I$. This quantity is relatively small, given the specialization of this company, although it does not strictly specialize in surfactants or their economic potential $(\$ 51,790,300,000$ in sales in 2002 ; Merck, 2003).

Abbott Laboratories published 20 articles. Its activity, though similar to that of Merck, emphasizes nutrition. Sales in 2002 were $\$ 17,684,000,000$, roughly a third of Merck sales. Despite this, it published a similar number of articles (Abbott Laboratories, 2003).

Firmenich, also with 20 publications, is one of the main perfume companies of the world, competing with Givaudan, IFF, and Dragoco. It produces perfumes, aromas and aromatic chemicals for application in cosmetics, cleaning products, food, and other products.

As can be seen, all the companies that have published an appreciable number of articles are long-established businesses (some more than a century old) that are multinational and have powerful human and economic resources.

\section{Researchers}

More than 125,000 authors have published at least one article on surfactants or related fields. This figure is spectacular, as it implies a population (including immediate family)

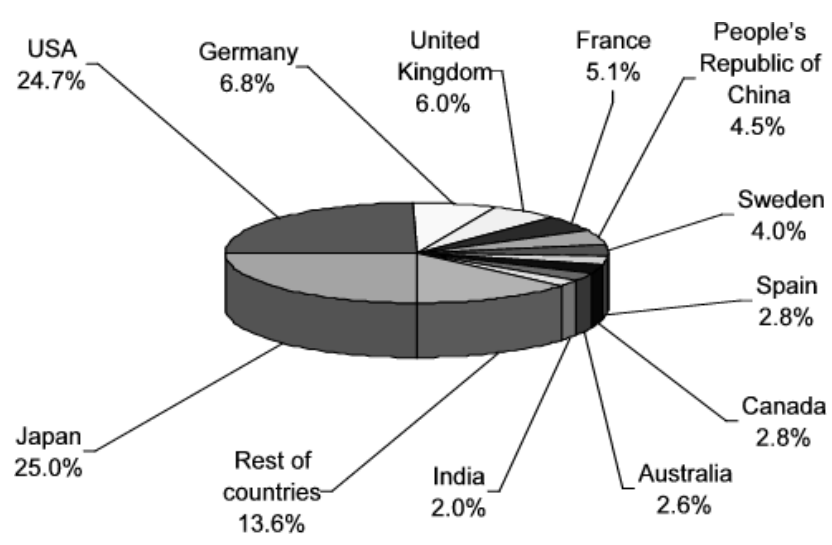

FIG. 6. Top researchers distributed by country.

sufficient to constitute a city of some half-million inhabitants. If we take into account Price's recommendation that the top producers be considered as the square root of the total of all authors (Price, 1963), the top group in this case would be 352 (with 25 or more articles) - that is, only $0.028 \%$ of the population of researchers.

Figure 6 shows that half of the top 352 researchers work in Japan or the United States of America, indicating the enormous power of these two countries - research is without any doubt distributed among many centers well equipped with human and technological resources. Table 1 presents the group of 10 researchers that in terms of their production of articles on surfactants (collected by the SCI database during the period considered) constitute part of the world's top researchers in this field. The three most productive authors (Whitsett, Ikegami, and Jobe) are from the United States and work in pediatric hospitals; this offers some idea of the importance of research on pulmonary surfactants for newborns. From fourth place on (R. Miller), most of the researchers work in centers dedicated to physics, chemistry, and pharmacy.

None of these researchers that are so productive work alone, of course; they are heads of research teams of greater or lesser size.

\section{Journals}

Among the most productive journals is the remarkable Langmuir, publishing 2,286 articles, representing no less than $3.6 \%$ of the total documents (today there are 4,071 different journals, of which it represents $1 / 28$ of the total production).

The following constitute a group of four that each produce roughly half the output of Langmuir: Physical Review D (1,233 articles), Journal of Colloid and Interface Science (1,176), Colloids and Surfaces A-Physicochemical and Engineering Aspects (1,113), and Journal of Agricultural and Food Chemistry (1,065). Of this group, the foremost is a general journal of reviews on physics, although series D focuses on physicochemistry of surfaces. The second and third specialize in colloids and interfaces (the third with applications in engineering), and the fourth, very different 
TABLE 1. Ten most productive researchers.

\begin{tabular}{|c|c|c|c|}
\hline Researcher & $\begin{array}{l}\text { Production } \\
\text { (articles) }\end{array}$ & Center & Country \\
\hline Whitsett, J.A. & 166 & Cincinnati Children's Hospital & United States \\
\hline Ikegami, M. & 133 & University of California Los Angeles, Children's Hospital & United States \\
\hline Jobe, A.H. & 102 & $\begin{array}{l}\text { University of California Los Angeles, Harbor UCLA } \\
\text { Medical Center, Children's Hospital, Cincinnati } \\
\text { Children's Hospital }\end{array}$ & United States \\
\hline Miller, R. & 100 & $\begin{array}{l}\text { University of Toronto, Max Planck Institute Kolloid and } \\
\text { Grenzflachenforsch, Chinese Academy of Science, } \\
\text { Max Planck Institute Colloid and Surface Chemistry, MPI, } \\
\text { MPI Kolloid and Grenzflachenforsch }\end{array}$ & Germany \\
\hline Penfold, J. & 94 & Rutherford Appleton Laboratory, Isis Facility, CCLRC & United Kingdom \\
\hline Kumar, S. & 87 & $\begin{array}{l}\text { Penn State University, University of Roorkee, Central } \\
\text { Institute of Medicinal \& Aromatic Plants, TS Coll, } \\
\text { University of Birmingham, CIMAP, University } \\
\text { of Michigan, Jawaharlal Nehru University, NCPGR }\end{array}$ & United Kingdom \\
\hline Goto, $\mathrm{M}$. & 86 & $\begin{array}{l}\text { Kyushu University, Mie University, Kumamoto University, } \\
\text { Gifu Pharmaceutica University, University of Tokyo }\end{array}$ & Japan \\
\hline Thomas, R.K. & 85 & $\begin{array}{l}\text { Physical Chemistry Laboratory, University of Oxford, } \\
\text { Physical and Theoretical Chemistry Laboratory, } \\
\text { Acad Clínica }\end{array}$ & $\begin{array}{l}\text { People's Republic } \\
\text { of China }\end{array}$ \\
\hline De La Maza, A. & 82 & Consejo Superior de Investigaciones Cientificas (CSIC) & Spain \\
\hline Parra, J.L. & 79 & Consejo Superior de Investigaciones Cientificas (CSIC) & Spain \\
\hline
\end{tabular}

from the others, publishes documents on agricultural and food chemistry.

Among the remaining journals are some dedicated to colloids and physicochemistry of surfaces, including polymers and macromolecules, along with journals on biochemistry and/or biomedicine and on analytical chemistry. There are also journals on detergents as well as on the environment; on biomedicine specializing in pediatrics, dermatology, and physiology; and on aromas and perfumery.

These classifications are made according to the title of the journals and are approximate. If the reader wishes to investigate in more depth the thematic profile of any journal, the publication sought may be processed with $\mathrm{CoPalRed}^{\odot}$ in a specific way and the thematic map of the journal will appear immediately as well as information on the actors (researchers, centers, etc.) associated with the journal.

In short, scientific journals that publish articles on surfactants are quite numerous; some are very specialized and highly productive, such as Langmuir. The journals can be classified into the following types:

1. Colloids and physicochemistry of surfaces

2. Polymers and macromolecules

3. Agricultural and food chemistry

4. Biochemistry and biomedicine

5. Analytic chemistry

6. Detergency

7. Environment

8. Medicine (pediatrics, physiology, dermatology)

9. Aromas and perfumes

\section{Thematic Map of the Major Research Areas}

Figure 7 provides a map of the major thematic areas of research in surfactants according to CoPalRed ${ }^{\odot}$. Most of the areas, and the greatest in relative weight in terms of number of documents, are aspects of physics and chemistry. However, biochemistry and cell biology, medicine (pediatrics and pulmonary physiology), and, to a lesser extent, veterinary medicine and food science and technology are also noteworthy aspects of the field of surfactants, which presents a markedly multidisciplinary profile.

A strategic diagram of the network is presented in Figure 8 . The volume of the spheres is proportional to the number of documents corresponding to each area. The abscissa axis is centrality, or the external cohesion index. It represents the most or least central position within the overall network of surfactants. The ordinate axis is density, or the index of internal cohesion. It represents the conceptual development of the theme or motor themes of the speciality, given that it presents strong centrality and high density. Those of the lower right quadrant (quadrant 2) are the most general basic themes, although with internal development not as high as those of quadrant 1 . The themes of quadrant 3 (upper left) are very specialized, but peripheral in character, while those of the lower left, with low density and little centrality, mainly represent either emerging or disappearing themes.

Next, the areas related to the physics and chemistry of the surfactants and that are of greater interest to the researchers are analyzed. 


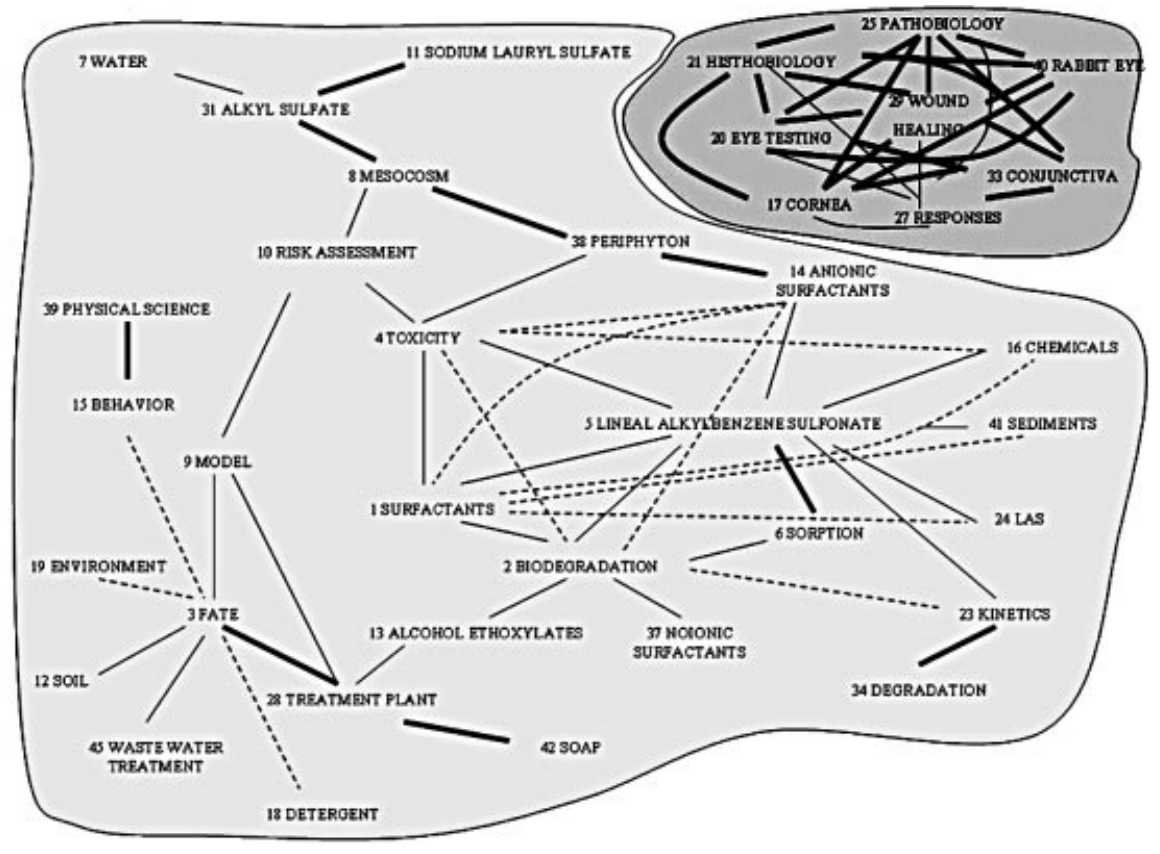

FIG. 7. Thematic map of the major areas of surfactants.

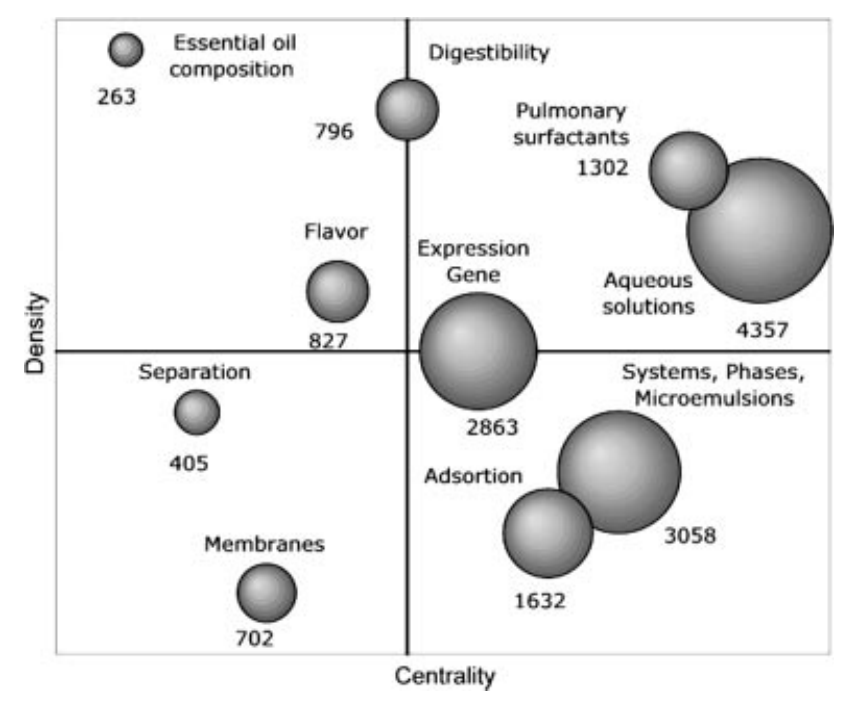

FIG. 8. Strategic diagram of the major areas of surfactants.

\section{Aqueous Solutions}

Description. The field of aqueous solutions involves the study of surfactants dissolved in aqueous media (Figure 9). Such study makes no special reference to the formation of phases, although it does to the phenomenon of micelles. All types of anionic surfactants are studied, fundamentally sodium lauryl sulfate, cationic and ionic. There is no explicit reference to amphoteric surfactants.

Of nonionic surfactants the emphasis is on the derivatives of ethylene oxide and propylene oxide in the form of block or triblock surfactants. The main influence on aqueous solutions of surfactants that are studied is that of the interaction of polyelectrolites. The preferred instrumental techniques are light scattering and fluorescence.

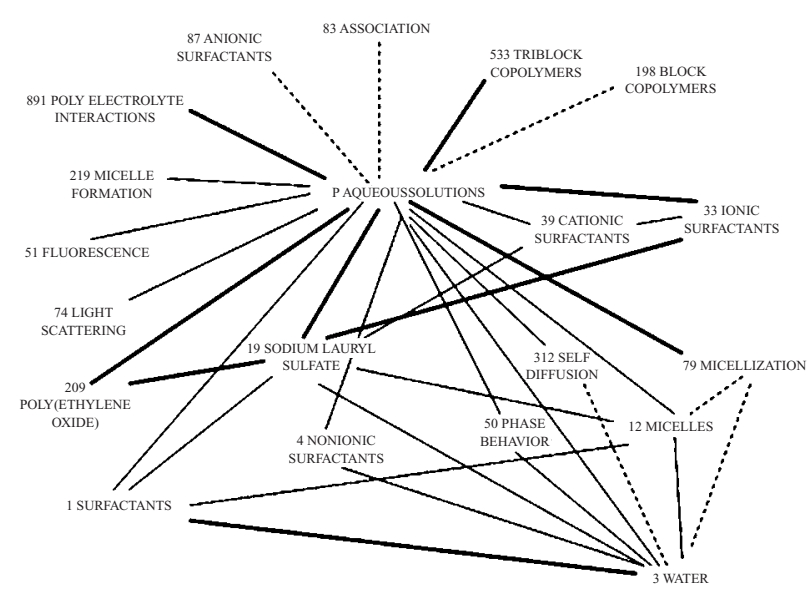

FIG. 9. Thematic area of aqueous solutions.

Strategic position. Centrality is 10.78 and density 3.56, equivalent to $100 \%$ and $70 \%$ of the maximal values of the network, respectively; the values place the thematic area in the upper right quadrant of the strategic diagram (Figure 8). This placement implies that this theme is quite related externally to concepts applicable to other themes that are conceptually closely related. In addition, the internal cohesion is also rather strong, and therefore we can consider aqueous solutions to be a motor area of the scientific field of surfactants.

This area maintains strong relationships with the area of systems, phases, and microemulsions, absorption, and membranes. These areas, mainly, form a larger whole that can be termed the physicochemistry of surfactants and colloidal systems. Furthermore, the small area of separation systems represents the annex area dedicated to experimental methodologies. Also, there are strong relationships with the "free" 


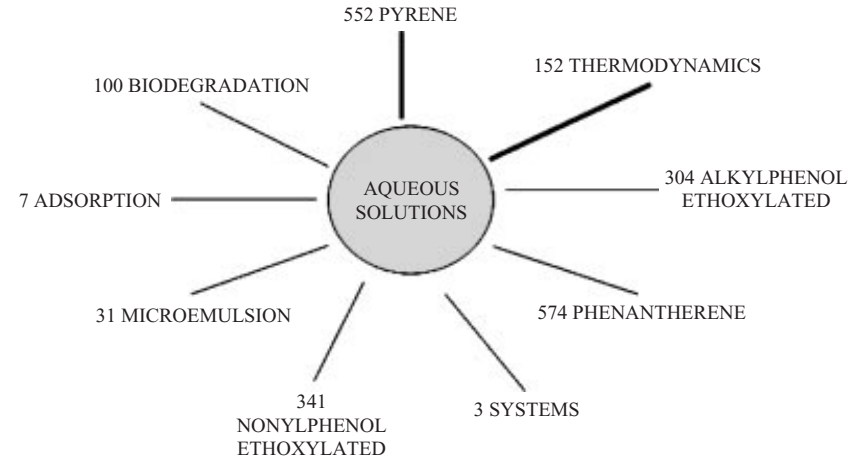

FIG. 10. External relationships of the area of aqueous solutions.

terms of some importance. Figure 10 displays some of the most representative links with free descriptors of other areas.

Actors. There are 4,357 documents that contain at least one link, making this the most extensive thematic area. The total number of journals is 529 , of which the following are the most outstanding:

1. Langmuir with 698 articles

2. Journal of Colloid and Interface Science with 401 articles

3. Colloid and Surfaces A with 377 articles

The remaining journals, some of which are very productive, publish substantially fewer documents.

Of a total of 8,397 authors, the most productive are the following:

1. B. Lindman, of the University of Lund, Sweden (59 articles)

2. R. Zana, appearing in many centers in Israel and France: Technion Israel, Institute of technology, Institute Charles Sadron, CNRS, University of Strasbourg 1, University Louis Pasteur, and Ben Gurion University Negev (45 articles published)

\section{Systems, Phases, and Microemulsions}

Description. The area of systems, phases, and microemulsions concerns structures and phase systems that form surfactants. The main descriptor is Systems, which because of its high frequency (in 2,578 documents) and multitude of possible relationships has difficulties in generating very intense links with other words. Therefore, this thematic area is characterized by having many weak links (Figure 11).

Striking for its strength is a subnetwork that comprises the terms Microemulsion, Reverse Micelles, and Aerosol OT. This subnetwork in turn is also related quite intensely to Systems and its fundamental experimental technique: Angle Neutron Scattering.

Therefore, in the study area of the systems of phases, the best-defined research line and probably the most vigorous is the study of microemulsions. However, apart from

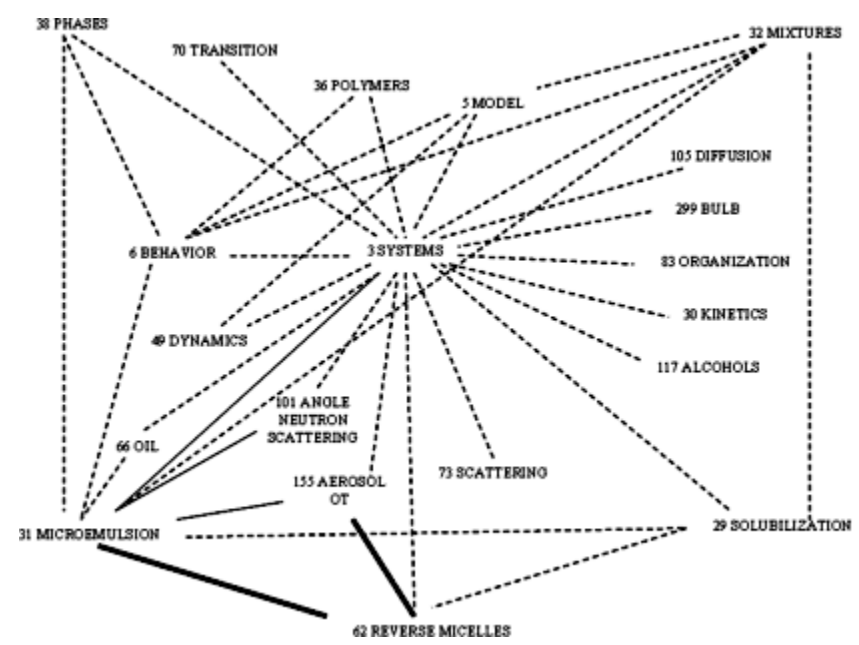

FIG. 11. Systems, phases, and microemulsions.

microemulsions, there are other aspects that are no less important. Some noteworthy triangular relationships appear and should be taken into account:

- Behavior, phases, and microemulsion

- Systems, behavior, and polymers

- Systems, model, and dynamics

- Behavior, model, and mixtures

- Solubilization, mixtures, and systems

In addition, linked exclusively to Systems, there are other elements that complete the overview of this area: Transition, Diffusion, Bulb, Organization, Kinetics, Alcohols and Scattering (here, this latter descriptor does not specifically interact with any type of diffusion method).

Strategic position. Centrality is 7.6 and density 1.416, implying a position in the lower right quadrant of the strategic diagram ( $80 \%$ and $30 \%$, respectively). The area is therefore very externally related: it forms part of the fundamental group we called physicochemistry of surfactants and colloidal systems. Thus, its very strong relationship is to the area of aqueous solutions, although it also has ample relationships with free descriptors. There are notable relationships with the term Microemulsion in Oil (which complements the concept of microemulsion, discussed previously) with octylglucosides, organic solvents, enzymes, reconstitution, polycyclic aromatic hydrocarbons, Triton $\mathrm{X}-100$, and others. Figure 12 offers a representation of the very intense external relationships-even more intense than the internal ones of the area-with other descriptors.

It can be concluded that those wishing to work at the heart of the physicochemistry of surfactants should work with phase systems, preferably microemulsions, or with closely related themes, such as glucosides, organic solvents, enzymes, and detergents.

Actors. In this thematic area, 3,058 specific documents appear over the 10 study years. If we take into account the 


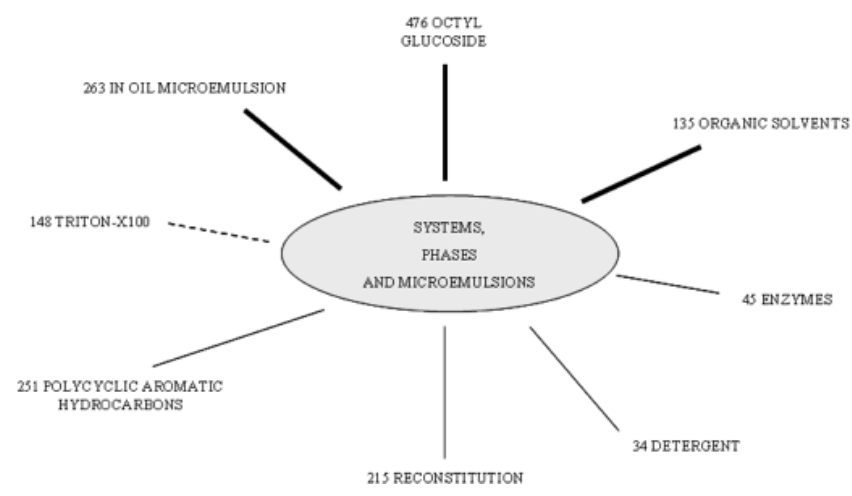

FIG. 12. External relationships of the area of systems, phases, and microemulsions.

strongly related external themes listed, the number may be somewhat higher: there are 207 with the term Microemulsions in Oil, 124 with Octyl Glucosides, 314 with Organic Solvents, 301 with Triton-X100, 612 with Enzymes, and so on.

The number of journals is 500; the most representative are Langmuir (with 452 articles), Colloids and Surfaces A (224), Journal of Colloid and Interface Science (211), Journal of Physical Chemistry B (118), and others similar in nature.

Of the 6,053 total published researchers, outstanding ones include the following:

1. U. Olsson (32 articles) of the University of Lund, Sweden

2. R. Strey (28 articles) of the Max Planck Institute, Biophysic Chemistry group, and University of Cologne, Germany

3. J. Eastoe (28 articles) of the University of Durham and University of Bristol, England

4. H. Kunieda (26 articles) of the National University of Yokohama, Japan

5. Heenan, Johnston, Kaler, and others at various centers

\section{Adsorption}

Description. Surfactants are molecules characterized basically by two properties: the first is their capacity to adsorb onto surfaces, and the second (a consequence of the first) is the ability to diminish greatly surface and interface tension. In this thematic area, studies are made chiefly on these two key aspects of physicochemistry of the surfactants.

Here, we find a rather pronounced star-shaped structure (Figure 13), which implies that the term Adsorption is related to a number of terms and concepts that are unrelated. An example: in the thematic area, reasearch is conducted on adsoption to particles (link Adsorption-Particles) and on the stability of adsorption (link AdsorptionStability); on the other hand, absolutely no research is done on the stability of particles, which is a very different concept. For these reasons, it is very important to analyze how terms are linked because a simple list can lead to completely erroneous conclusions.

In the figure, we find an especially well-linked subnetwork consisting of the terms Adsorption, Water Interface, Air-Water Interface, Monolayers, and Layers. This means

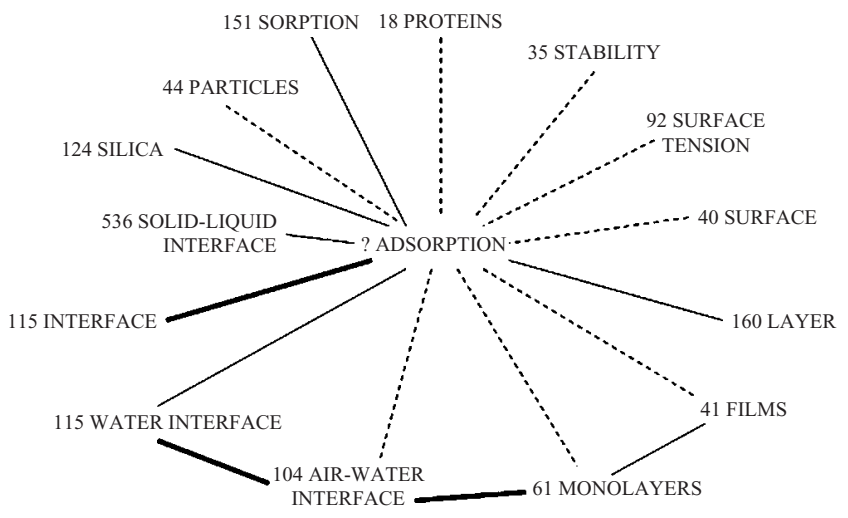

FIG. 13. Thematic area of adsorption.

that strictly under the control of the phenomenon of adsorption, preferential research involves interfaces, and more particularly aqueous interfaces, and among these, the interfaces that water forms with the air, producing surfactant monolayers and films.

It should be noted furthermore that there are research lines not only on interfaces in aqueous media, but also on liquid-solid interfaces, on adsorption to silica, on different types of particles, on proteins, and, as a primordial question, on the stability of this adsorption.

Figure 14 shows the main external liaisons. It is observed that it connects with the words Detergent and Enzyme, and through them, connects therefore with the area of Systems.

Strategic position. Centrality is 4.91 , which represents $70 \%$, and density is 1.36 , equivalent to $20 \%$. As in Systems, Phases, and Microemulsions discussed earlier, the position is the lower right quadrant (high centrality, low density).

Actors. The number of documents is 1,632 , and the total number of journals 348 , of which the following are most representative:

1. Langmuir (226 documents)

2. Journal of Colloid and Interface Science (196 documents)

3. Colloids and Surfaces A (183 documents)

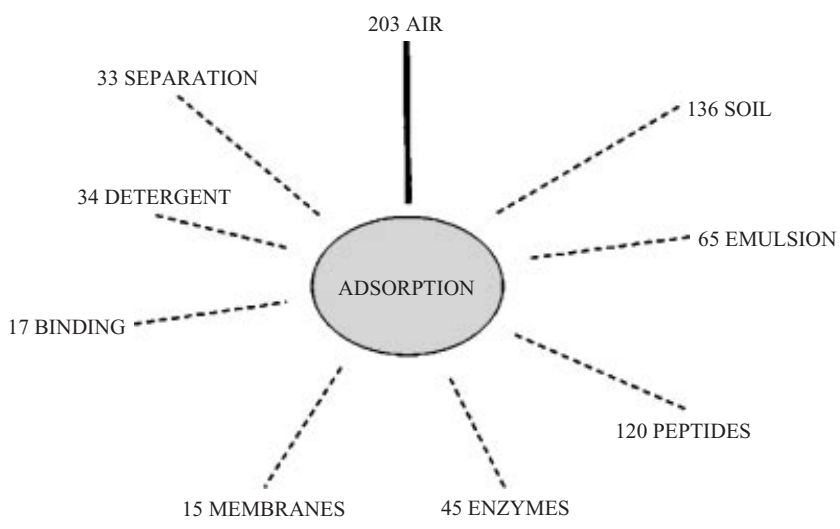

FIG. 14. External relationships of the area of adsorption. 
The closeness of the Adsorption themes to the previously mentioned areas makes the journals practically the same. On the other hand, the leading researchers are not necessarily the same:

1. J. Penfold, of Rutherford Appleton Lab, England (49 articles)

2. R. Thomas, of Oxford University, England; Chinese Academy of Sciences, China (47 articles)

3. R. Miller, Max Planck Institute (where he has his research team); University of Toronto, Canada; Chinese Academy of Sciences, China (30 articles)

\section{Membranes}

Description. The thematic area of Membranes involves, essentially, complex liposome-type structures-that is, structures in the form of vesicles with a membrane structured in bilayers. The indispensable substance is phosphatidylcholine.

This thematic area has conceptually very limited dimensions, as we will see, and very few actors. Also, it has only seven descriptors, a very low number, considering that CoPalRed $^{\odot}$ worked under the conditions that it could construct networks of up to 20 descriptors. The links are also few and weak (Figure 15).

Strategic position. Of all the areas, this is the one in the most disadvantageous position. Its centrality (2.149 and $30 \%)$ and its density (1.334 and $10 \%)$ are very low, situating it in the lower left quadrant of the strategic diagram (Figure 8). If it remains in this position, it may dwindle and eventually disappear from exhaustion.

Actors. Under the actors theme, the SCI lists 702 articles from 1993 to 2002; this is a relatively small area. The total of journals was 252; Langmuir had 45 documents. Other journals, mentioned previously, were also quite productive: Journal of Colloid and Interface Science (30) and Colloids and Surfaces A (23). In addition, other more specific ones appear:

1. Biochimica et Biophysica Acta-Biomembranes (36)

2. Biochemistry (17) (this journal is more generic)

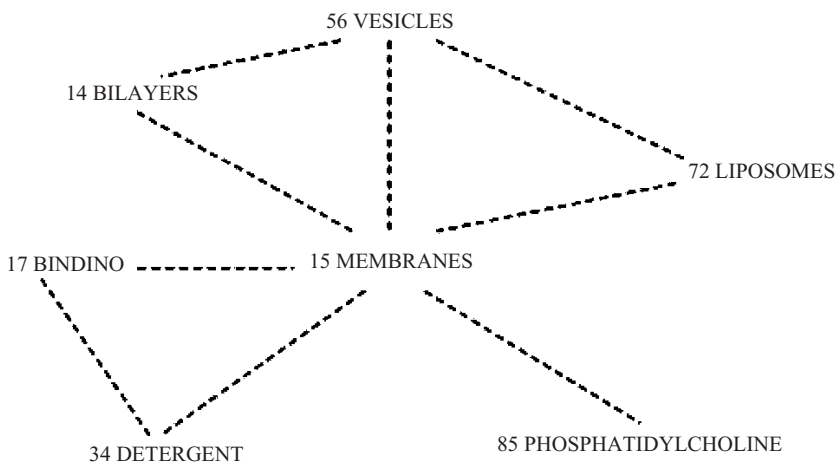

FIG. 15. Thematic area of membranes.
3. International Journal of Pharmaceutics (15)

4. American Journal of Physiology_Lung Cellular and Molecular Physiology (15)

The most important researchers-and this is not usualall work for the same center: the CSIC of Spain. Of a total of 2,066 authors, practically all publish occasionally except for the team indicated, who occupy the first five positions worldwide:

1. A. De la Maza (46 articles)

2. J.L. Parra (44 articles)

3. O. López (17 articles)

4. L. Coderch (15 articles)

5. M. Cocera (11 articles)

This area is dominated primarily by these researchers and by the effort of the CSIC (Spain), the research center that, as noted, is the most productive in the world.

\section{Techniques of Separation}

Description. The theme of description (because of its size, calling it a thematic area would not be correct) does not in itself pertain to the area of surfactants, but rather it is a set of techniques and methodologies that were introduced from outside the network and are necessary for experimental work. Basically it consists of separation techniques: electrophoresis, chromatography, and extraction. These techniques, being rather general, appear in a separate theme, as other more specific ones, such as light or neutron scattering, have appeared mixed with other areas analyzsed earlier. The network is the one specified in Figure 16, where an external link has also been drawn to Mass Spectrometry.

Strategic position. As indicated in the strategic diagram (Figure 8), this theme has an unfavorable position. This is not surprising, given that it is, finally, a group of techniques that are strange within the network (low centrality) and methodologically different with respect to one another (low density). The only feature that they have in common is that they are useful for separations and are frequently used in laboratory work with surfactants_-and nothing more.

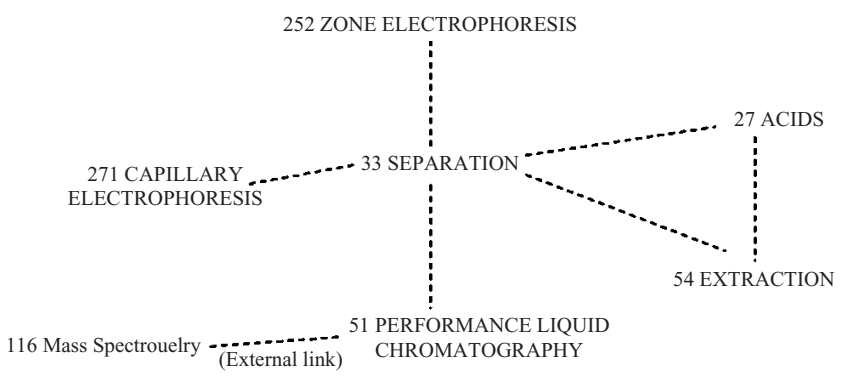

FIG. 16. Theme, techniques of separation. 
Actors. The number of articles is low (405), as is the number of journals (96), of which the most productive are, understandably, specific to these methodologies:

1. Journal of Chromatography A (64 articles)

2. Electrophoresis (47 articles)

3. Analytical Chemistry (33 articles)

4. Chromatographia (21 articles)

In terms of authors, there is no real specialist. The most noteworthy are

1. M. Goto of the University of Kyushu, of Kumamoto, of Mie, of Gifu Pharmaceut, and of Tokyo (Japan) (10 articles).

2. F. Nakashio of the University of Kyushu (9 articles)

\section{Other Areas}

We have considered the areas of the physicochemistry of surfactants. The rest of the areas are not analyzed because they are outside the interest of the most of the researchers.

\section{Conclusions}

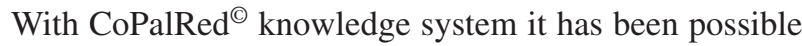
to analyze the scientific network of the surfactants. CopalRed $^{\odot}$ uses activity and relational indices and for that reason allows one to make, for example, combined studies of productivity and scientific maps. This article analyzes a set of 63,543 bibliographic references of scientific articles within the period 1993-2002. The actors studied are countries, research centers and laboratories (state-owned nonuniversity research centers, universities, and companies), researchers, and journals. In addition, the thematic map of the major research areas has been established. Most of the areas, and those that have the greatest relative weight by number of documents, are aspects of physics and chemistry. Biochemistry and cell biology, medicine (pediatrics and pulmonary physiology), and, to a lesser extent, veterinary medicine and food science and technology are also noteworthy specialties of the field of surfactants, which presents a markedly multidisciplinary profile.

\section{Acknowledgments}

This study was supported by the Spanish Ministry of Science and Technology through projects no. 1FD97-0931 and PB1998-1293.

\section{References}

Abbott Laboratories. (2003). Abbott Laboratories. Retrieved 2003, from http://abbott.com/

Bailón-Moreno, R. (2003). Ingeniería del conocimiento y vigilancia tecnológica aplicada a la investigación en el campo de los tensioactivos: Desarrollo de un modelo ciencimétrico unificado. Unpublished Ph.D. thesis, Universidad de Granada, Granada, Spain.
Cahlik, T. (2000). Comparison of the maps of science. Scientometrics, 49(3), 373-387.

Callon, M., Courtial, J.P., \& Laville, F. (1991). Co-word analysis as a tool for describing the network of interactions between basic and technological research: The case of polymer chemistry. Scientometrics, 22(1), 155-205.

Callon, M., Courtial, J.P., \& Penan, H. (Eds.). (1995). Cienciometría: La medición de la actividad científica: De la bibliometría a la vigilancia tecnológica. Gijón: Trea.

Cognis. (2003). Cognis. Retrieved 2003, from http://www.cognis.com/ cognis.html

Courtial, J.P. (1989). Qualitative models, quantitative tools and network analysis. Scientometrics, 15(5-6), 527-534.

Courtial, J.P. (Ed.). (1990). Introduction a la scientométrie: De la bibliométrie a la veille techonologique. Paris: Anthropos

Courtial, J.P. (1997). Le rôle des mots d'indexation dans la mise en évidence de la dynamique d'un domaine scientifique: Exemples de l'ethnopsychiatrie et de l'autisme. Documentaliste-Sciences De L'Information, 34(3), 135-141.

Courtial, J.P., \& Callon, M. (1991). Indicators for the identification of strategic themes within a research programme. Scientometrics, 21(3), 447-458.

Courtial, J.P., Callon, M., \& Sigogneau, A. (1993). The use of patent titles for identifying the topics of invention and forecasting trends. Scientometrics, 26(2), 231-242.

Courtial, J.P., \& Michelet, B. (1990). A mathematical model of development in a research field. Scientometrics, 19(1-2), 127-141.

The Dow Chemical Company. (2003). Henkel-A brand like a friend. Retrieved 2003, from http://www.dow.com/Homepage/index.html

Henkel KGaA (2003). Henkel—a brand like a friend. Retrieved 2003, from http://www.henkel.com/int_henkel/company/index.cfm

Jurado-Alameda, E., Bailón-Moreno, R., \& Ruiz-Baños, R. (2001). Análisis estratégico de los temas de investigación en el campo de los tensioactivos. In XIX Jornadas de Ingeniería Química: Los Indicadores de Calidad en Ingeniería Química (pp. 69-77). Santander: Universidad.

Jurado-Alameda, E., Bailón-Moreno, R., \& Ruiz-Baños, R. (2002a). Evaluación a través del Análisis de las Palabras Asociadas: 1. Aplicación a la investigación científica y técnica. Ingeniería Química, 34(388), 141-149.

Jurado-Alameda, E., Bailón-Moreno, R., \& Ruiz-Baños, R. (2002b). Evaluación a través del Análisis de las Palabras Asociadas (y II): Evaluación de la investigación en el campo de los tensioactivos. Ingeniería Química, 34(389), 177-184.

Kao Corporation (2002). Kao Corporation. Retrieved 2003, from http:// www.kao.co.jp/e/

Law, J., \& Whittaker, J. (1992). Mapping acidification research: A test of the co-word method. Scientometrics, 23(3), 417-461.

Leydesdorff, L. (2003). A methodological perspective on the evaluation of the promotion university-industry-government relations. Small Business Economics, 70, 201-204.

Merck (2003). Merck \& Co., Inc. is a leading research-driven pharmaceutical products and services company. Retrieved 2003, from http://www. merck.com/

Noyons, E. (2001). Bibliometric mapping of science in a science policy context. Scientometrics, 50(1), 83-98.

Polanco, X. (1997). Infometría e ingeniería del conocimiento: Exploración de datos y análisis de la información en vista del descubrimiento de conocimientos. In H. Jaramillo \& M. Albornoz (Eds.), Segundo Taller Iberoamericano Sobre Indicadores en Ciencia y Tecnología (pp. 335350). Cartagena de Indias, Colombia: Tercer Mundo.

Price, D.J.d.S. (Ed.). (1963). Little science, big science. New York: Columbia University Press.

Procter \& Gamble (2003). Procter \& Gamble: Your resource for family, personal and household care. Retrieved 2003, from http://www.pg.com/ main.jhtml

Rip, A., \& Courtial, J.P. (1984). Co-word maps of biotechnology: An example of cognitive scientometrics. Scientometrics, 6(6), 381-400. 
Rostaing, H. (Ed.). (1996). La bibliométrie et ses techniques. Toulouse: Sciences de la Société y Centre de Recherche Rétrospective de Marseille

Ruiz-Baños, R. (1997). Ciencimetría de redes: Análisis de la investigación internacional sobre Arqueología mediante el método de las Palabras Asociadas (1980-1993). Unpublished Ph.D. thesis, Granada: Universidad.

Ruiz-Baños, R., \& Bailón-Moreno, R. (1998). El método de las Palabras Asociadas: 1. La estructura de las redes científicas. Boletín de la Asociación Andaluza de Bibliotecarios, 53, 43-60.
Ruiz-Baños, R., \& Bailón-Moreno, R. (1999). El método de las Palabras Asociadas: 2. Los ciclos de vida de los temas de investigación. Boletín de la Asociación Andaluza de Bibliotecarios, 54, 59-71.

Stegmann, J., \& Grohmann, G. (2003). Hypothesis generation guided by co-word clustering. Scientometrics, 56(1), 111-135.

Unilever (2003). Unilever-International manufacturer of leading brands in foods, home care and personal care. Retrieved 2003, from http://www. unilever.com/

Universidad de Granada. (2005). Sistema de conocimiento CoPalRed ${ }^{(}$ Retrieved 2005, from http://ec3.ugr.es/copalred 